\title{
Chapter 14 \\ Climate Change and the Rise and Fall of the Oxus Civilization in Southern Central Asia
}

\author{
Élise Luneau
}

\begin{abstract}
During the Final Bronze Age (around 3750/3700 BP), the proto-urban sedentary cultural entity in southern Central Asia-known as the Oxus civilization or Bactria-Margiana Archaeological Complex-underwent major social transformations in different field aspects leading to a deep cultural change in the middle of the 4th millennium BP. Among the different reasons suggested to explain these sociocultural changes, the hypothesis of global climate change in Central Asia at the beginning of the 4th millennium BP has been emphasized by different scholars. In this paper, I will examine current paleo-environmental data in relation with the climate evolution during the Mid- and Late Holocene. A critical assessment of the hypothesis of climatic change in Central Asia at the beginning of the 4th millennium BP allows to stimulate the discussion anew. I argue that the present data do not support a drastic climate change during the first half of the 4th millennium BP as a responsible factor for the fall of the Oxus civilization, although local environmental modifications should also not be underestimated and further investigated in a more integrated perspective of co-evolution of the ecological environment and the human societies.
\end{abstract}

Keywords Central Asia $\cdot$ Bronze age $\cdot$ Oxus civilization/BMAC Climate variation $\cdot$ Sociocultural evolution $\cdot$ Collapse

\subsection{Introduction}

The issue concerning the variability of the climatic system, its impact on sociocultural changes and human action on climate is currently strongly debated in view of the present-day situation of climate disruption. This topic causes controversy, which often derives from determinism—environmental or anthropic —and/or

É. Luneau (凶)

Eurasia Department, German Archaeological Institute, Im Dol 2-6, Haus II,

14195 Berlin, Germany

e-mail: elise.luneau@dainst.de

(C) The Author(s) 2019

L. E. Yang et al. (eds.), Socio-Environmental Dynamics along the Historical Silk Road, https://doi.org/10.1007/978-3-030-00728-7_14 
denials, although the co-evolution and co-adaptation of people and environment has recently been proposed (Dearing 2006; Holdaway et al. 2013; Kirch 2005; Morales et al. 2009).

Numerous scholars put forward the idea that environmental modifications can be the vector of change, or at least can act to develop and amplify internal tensions within society. Thereby, climatic causes are frequently assumed in the case of disappearance of past societies and cultural entities, revealing both the resilience and the vulnerability of complex societies to climate change (Dalfes et al. 1997; deMenocal 2001), such as for instance, the Akkad Empire (Cullen et al. 2000; Kuzucuoğlu and Marro 2007; Weiss 2017; Weiss and Courty 1993), the Indus civilization (Giosana et al. 2012), the Maya civilization (Haug et al. 2003) or the Tiwanaku civilization (Binford et al. 1997). This is also true in case of the Oxus civilization, which occupied southern Central Asia and north-eastern Iran during the Bronze Age (Fig. 14.1) between the second half of the 5 th and the middle of the 4 th millennium BP. ${ }^{1}$ Some scholars have tried to explain this fall by considering " $a$ disturbance of the equilibrium in the eco-social system induced by the growing aridity of the climate and by the resultant decline in agroclimatic potential" (Dolukhanov 1981: 383). Climate variation then is a crucial question for understanding the interplay of the environmental and anthropic factors in the evolution of the Oxus civilization.

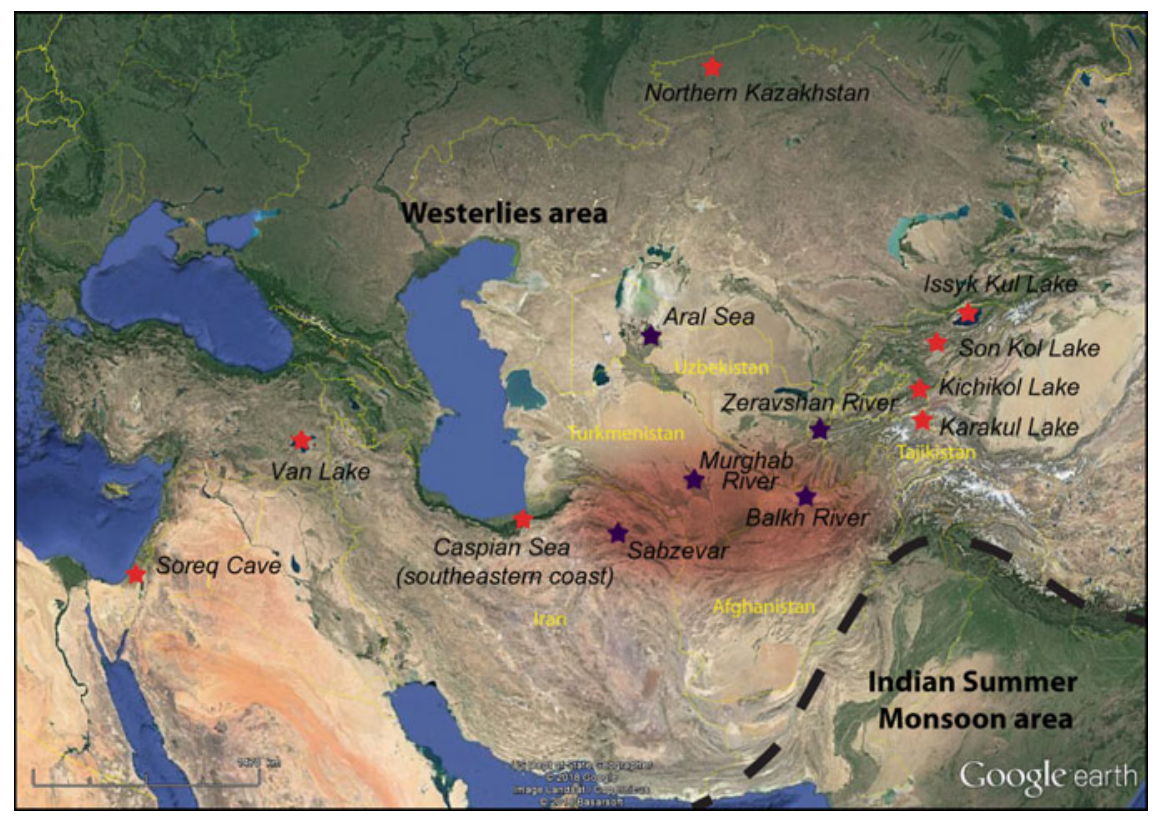

Fig. 14.1 Location of the Oxus civilization and of the mentioned palaeoclimatic records (in red) and geomorphological/geoarchaeological studies (in blue)

\footnotetext{
${ }^{1}$ The datations BP (Before Present) use the year 1950 as a reference point for "the present".
} 
The relation between climatic, environmental and societal change is not direct (Wilkinson 2003), and the impact of climate variation on human actions is far from clarified (d'Alpoim Guedes et al. 2016). The crossing of the disciplines and approaches-environmental studies with anthropology — enlightens the reciprocal interaction between Human and Environment, and offers to encompass the natural processes as well as to highlight the constant adaptations of societies and environments. Climatic change is a complex, multifaceted and multiscalar phenomenon, and, besides the extent of climatic change, the reaction of human societies is essential in order to elucidate the interaction between climate change and social evolution (Butzer 2012).

This article proposes a cross-over study of archaeological evidence and current palaeo-climatic data for a critical review of the hypothesis of climate variation as sufficient to cause the sociocultural evolution of the southern Central Asian protourban culture at the end of the Bronze Age. It also examines the variability of the climate cause-effect chain and of consequences of environmental changes.

\subsection{Short Note on the Geography of Southern Central Asia and Northern Iran}

The territory of the Oxus civilization covers southern central Asia and north-eastern Iran, approximately between the Aral Sea drainage basin and the Dasht-e Kavir desert on the Iranian plateau, mainly between the latitude $35^{\circ}$ and $40^{\circ}$ north (Fig. 14.1).

As one of the driest areas in the world, southern Central Asia is undergoing the influence of different climatic systems at different space and time scales, but presently dominated by prevailing winds from the West, so-called 'westerlies' (Cheng et al. 2012, 2016; Heinecke et al. 2016; Lauterbach et al. 2014; Wang et al. 2010). It belongs to the desert climatic zones, with a semi-arid to arid climate, characterized by low rainfall from the end of fall to mid spring and by a maximum exposure to the sun and high temperatures the rest of the year (Mannig et al. 2013). 90\% of this area receives less than $400 \mathrm{~mm}$ of precipitation per year (De Pauw 2007; Fig. 14.2).

This fragile ecosystem is very sensitive to changes and depends greatly upon water resources (Gessner et al. 2013). The availability of water (more than the temperatures) has always been of crucial significance for the evolution of human settlement patterns, explaining the uneven population distribution and the relocation of sites throughout time.

The high mountain system, such as the Pamir and Tian Shan which extend towards the West into the Mountains Alai or Turkestan slit along by long and narrow valleys, as well as medium mountains such as the Kopet Dagh range delineating Turkmenistan and Iran, are of major importance in Central Asia, especially as headwaters of numerous rivers (for instance, Amu-Darya, Syr-Darya and their tributaries). The mountain ranges present a stepped relief with different ecotopes (highlands, foothills, alluvial terraces and valley floors) allowing a diversity of economic strategies. The alpine zone or the high plains - such as the Khorasan landscape in northern Iran - are mostly covered by steppe-like vegetation. The foothills watered by small mountain rivers are covered by montane and sub-alpine vegetation (pasture lands and forests). Below, 


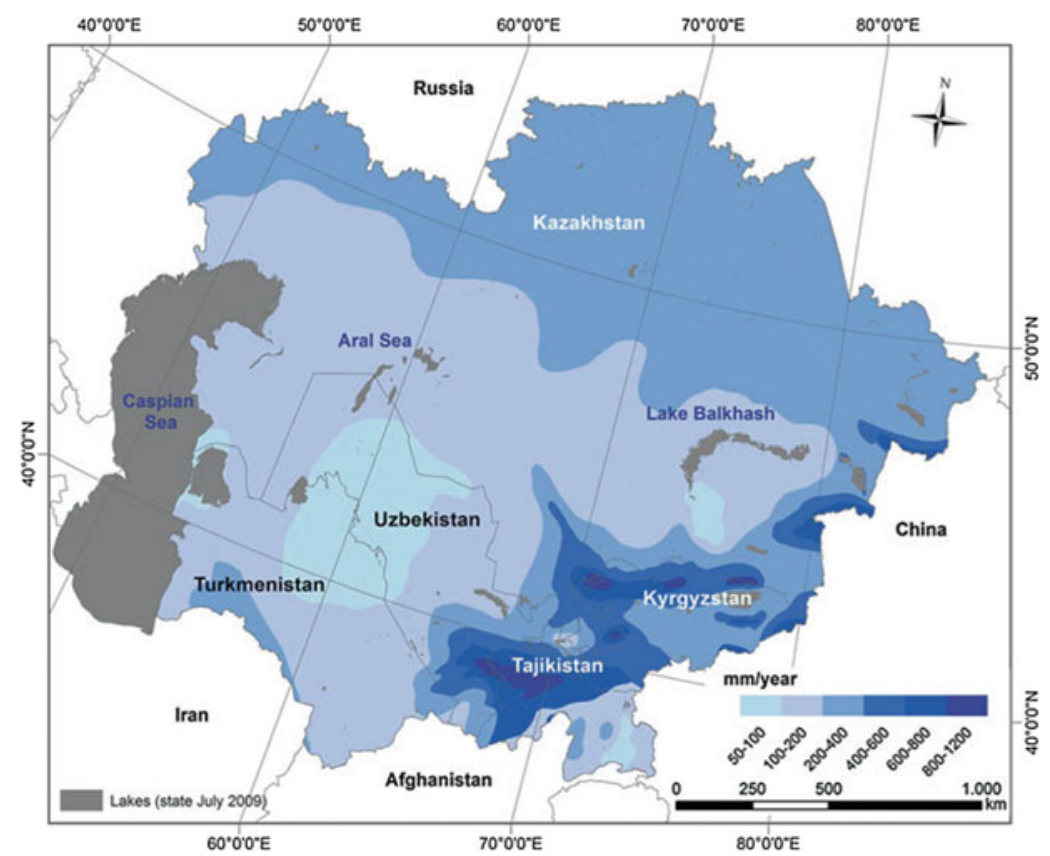

Fig. 14.2 Distribution of the precipitations over Central Asia (after Mueller et al. 2014: 17, Fig. 7)

terraces and river plains are constituted by a thick layer of fertile sediments deposited by the wind (loess) allowing cultivation.

Besides, most of this area are deserts (Karakum and Kyzylkum mainly located in present Turkmenistan and Uzbekistan), covered by Irano-Turanian steppe vegetation with a high variation determined by the climate (Djamali et al. 2012). Water resources are supplied by diverse courses spreading across alluvial fans: for example, the Murghab River in central Turkmenistan and the Balkh River in northern Afghanistan flanked by relatively dense, natural vegetation called tugai consisting of riparian forest or woodland associated with fluvial and food plain areas (Aishan et al. 2015). Seasonal floods contribute to the cultivation of lands, but agriculture mostly relies on irrigation practices in these areas.

In short, the landscape of the southern part of Central Asia consists of very varied and fragile ecological zones. This environmental variability emphasizes the importance of considering specific localized ecological conditions, which do affect our understanding of the global environmental systems (mechanisms and effects of the evolution) and do impact the sustainability of the resources exploitation and the lifestyles in the different areas of Central Asia. 


\subsection{The Oxus Civilization or Bactria-Margiana Archaeological Complex (BMAC)}

Despite the aridity, southern Central Asia has a long history of sedentism based on agropastoral economy since the Neolithic, necessarily determined by water management. Most of the population lived along the banks of rivers or in the mountain foothills, which were better suited for agricultural use, while the climatic conditions in the mountainous areas were adequate for livestock breeding and dry agriculture. In the Bronze Age, the Oxus civilization developed between ca. 4250-3350 BP (Kohl 2007; Francfort 2009; Lamberg-Karlovsky 2012; Lyonnet and Dubova in press). The rise of the Oxus civilization is still unclear, and this ensemble is better known and defined as the mature phase (ca. 4250-3750 BP), where a specific material culture presents a large homogeneity over a vast territory in current northern Iran, southeastern and central Turkmenistan, northern Afghanistan, southern Uzbekistan and southern Tajikistan (Fig. 14.1).

The Oxus civilization played a significant role in the system of exchange in Middle Asia-sometimes called Middle Asian Interaction Sphere (Kohl 2007; Possehl 2007) - for raw material (gold, lapis lazuli, turquoise, alabaster, tin, etc.) and finished items. Specific objects related to this culture have also been recorded in neighboring areas (Zeravshan valley, Ferghana valley, Indo-Pakistani area, Gorgan plain, Arabian peninsula, etc.). At that time, along with the long distance trade, the cultural entity experienced increasing proto-urban development, social stratification, task specialization, territorial expansion and homogenization. Populations lived in mudbricks or adobe houses in settlements of varying sizes. Monumental architecture, specific burial practices as well as prestige and luxury goods reflect a hierarchized society, possibly organized as proto-state. Numerous aspects linked to the exploitation of natural resources need further research, but the populations practiced agropastoralism in a complex socioeconomic pattern with a rich and diversified agricultural production along with the husbandry of diverse animals. The productions in ceramic, metal and stone reveal an extraordinary handicraft related to the skills gained by specialist craftsmen and the iconographic wealth exposing a singular symbolic system, connected with the Middle East but also locally rooted. Large questions are still open on the language(s) spoken by the populations-indo-iranian, proto-tokarian, elamite or unknown - as well as on the religion associated with this culture without writing.

\subsection{The Fall? Overview of the End of the Oxus Civilization}

From c. 3750/3650 BP onwards, the Oxus civilization progressively underwent major sociocultural transformations (Table 14.1); the last cultural features related to it disappeared around $3400 / 3350 \mathrm{BP}$ with the manifestation of new significant changes, identified as the beginning of the Early Iron Age (Luneau 2014, in press). This long period of change has often been perceived as the collapse of the previous urban system. 
Table 14.1 Summary of the major transformations in different sociocultural areas of the Oxus civilization during the Final Bronze Age (ca. 3750-3350 BP)

\begin{tabular}{|c|c|}
\hline & Transformations/evolutions \\
\hline Settlement pattern & $\begin{array}{l}\text { - Abandonment and reduction in size of sites } \\
\text { - But territorial expansion? }\end{array}$ \\
\hline Material culture & $\begin{array}{l}\text { - Changes in the quantity of items and in the morphology } \\
\text { - Higher variability in the morphology of the ceramic complex } \\
\text { - Appearance of miniature metallic items } \\
\text { - Higher portion of material related to the northern central Asian } \\
\text { traditions } \\
\text { - Less cultural homogeneization }\end{array}$ \\
\hline $\begin{array}{l}\text { Sociopolitical } \\
\text { organization }\end{array}$ & $\begin{array}{l}\text { - Disappearance of the monumental architecture } \\
\text { - Disappearance of the previous social status markers }\end{array}$ \\
\hline $\begin{array}{l}\text { Exchanges and } \\
\text { Trade }\end{array}$ & $\begin{array}{l}\text { - Slackening of the interregional exchanges, with a possible change of } \\
\text { direction of the trade } \\
\text { - Higher contacts with the mobile populations related to the } \\
\text { "Andronovo" community }\end{array}$ \\
\hline Ideology and beliefs & $\begin{array}{l}\text { - Diversification of the burial practices } \\
\text { - Disappearance of the figurative expressions, especially mythological }\end{array}$ \\
\hline $\begin{array}{l}\text { Subsistence } \\
\text { economy }\end{array}$ & $\begin{array}{l}\text { - Possible evolution of the subsistence economy towards a more pastoral } \\
\text { and more mobile economy }\end{array}$ \\
\hline
\end{tabular}

Despite the lack of study on this period viewed as unattractive and the numerous gaps in the state of research, the available data provide nevertheless a solid basis for questioning the evolutionary process of the southern central Asian society during the first half of the 4th millennium BP. These mutations are indeed complex and diverse, such as innovations or changes alongside the oldest traditions, and permanencies also coexisted with the previous period (Luneau 2014, 2015). The settlement pattern shifted towards a reduction in the size of sites. The abandonment of sites is also noticeable, but this occurred parallel with the appearance of new sites and a possible territorial expansion. Changes are also obvious in the material culture, in the quantity of items discovered at the sites as well in their morphology. The ceramic production was affected by a higher variability. Technological processes seem globally similar with a trend to less investment of time and skills in the production. Metallurgy was also affected by sociocultural changes, mainly concerning the size rather than the shape of the items and the greater presence of artefacts related to the "steppe Bronze Age" cultures, as well as by the technological progression of the bronze metallurgy. A less cultural homogeneity over the whole territory of the Oxus civilization is also noticeable. Modifications are likewise clearly visible in the sociopolitical organization with the disappearance of social status markers, in connection with the slackening of the long-distance exchange networks. Trade appears to have been more active among the mobile populations referred to as belonging to the "Andronovo Cultural Community" than with the Middle Eastern cultures, as was previously the case. This situation can be particularly explained by the greater presence and influence of mobile populations in southern Central Asia (Cattani 2008; Cerasetti 2012; Fra- 
chetti and Rouse 2012; Luneau 2017; P'jankova 1994; Vinogradova and Kuz'mina 1996). The diversification of burial practices, correlated to the disappearance of the figurative, especially mythological, expressions likely indicates a major shift in the ideological and symbolic beliefs. The socioeconomic profile, as far as we know, seemed not to strongly change throughout the duration of the Oxus civilization. Irrigation was maintained, and the plants exploited vary little, excepting for the possible rise of the use of millet (see below). Herding also might have increased in relation to an increased exploitation of the highlands.

All in all, the long evolution, which occurred over 300 years at least, rather appears as a (transitional) phase of a slow sociocultural reconfiguration at the roots to a less urban, less concentrated, possibly less hierarchical society in the second half of the 4th millennium BP (Early Iron Age).

\subsection{The Environmental Hypothesis as Responsible for the Changes of the Oxus Civilization}

Among the different explanations for these changes, the impact of climate has been frequently proposed, although opinions differ on climate changes in southern central Asia.

Numerous scholars (Dolukhanov 1981, 1988; Gentelle 2001; Koshelenko et al. 1994; Ljapin 1990; Mousavi 2008; Vinogradov and Mamedov 1974) assert that the climatic conditions were more humid during the Mid-Holocene, ${ }^{2}$ between 8950 and 3950 BP. A drastic drying of the climate then happened, around 3950/3750 BP, inducing important environmental changes and impacting human societies.

This phenomenon also emerged as an explanation for the fluctuations of the hydraulic system in the Murghab alluvial fan in central Turkmenistan, where the geomorphological dynamic may have determined the location of ancient settlements. The retraction of the alluvial fan with the desertification of the north-eastern distal part of the channel networks over time has been observed (Cremaschi 1998). This would have resulted from the progressive decrease of the Murghab River, on one hand, and the constant sand movement carried by the northern winds in the Karakum desert, on another hand.

In consequence, the aridification process would have been modified the courses of the rivers, depleted the water supply and reduced the agricultural land potential. It would have involved a demographical pressure, causing a reduction in population density, thus leading to depopulation and a shift in settlement patterns. The hypothesis was consolidated by the first results on the periodization of different Bronze Age sites, which has now been proven to be incorrect. At that time, the chronological overview suggested the existence of non-contemporaneous independent groups of sites called 'oases', whose successive occupation followed the retraction of the alluvial fan to the South, downstream-upstream, with the desiccation of channels (Masimov 1981; Sarianidi 1981, 1990: 64). The distribution of the sites since the early phases of

\footnotetext{
${ }^{2}$ The Holocene is defined as the current geological period, which began approximately 11,700 years BP. It is commonly divided into three sub-periods (Walker et al. 2012): the Early Holocene (11,700-8200 BP), the Mid-Holocene (8200-4200 BP) and the Late Holocene (4200 BP-present).
} 


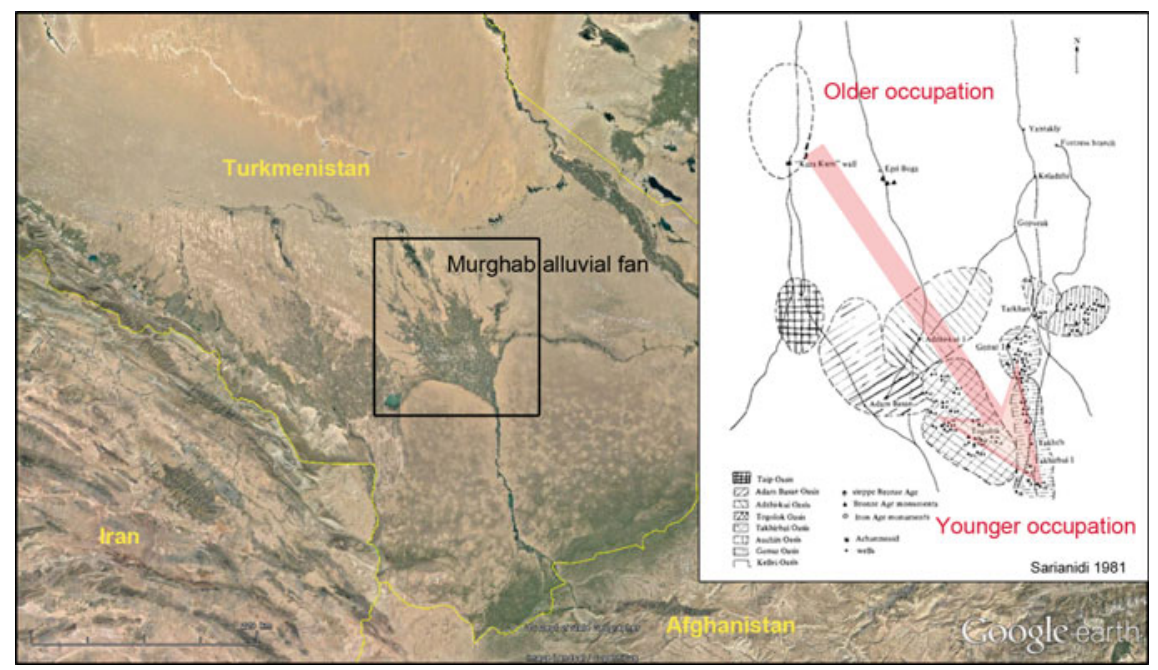

Fig. 14.3 Location of the Murghab alluvian fan and schematic map of distribution of the archaeological sites

the Bronze Age in the North until the Iron Age in the South (Fig. 14.3; Kohl 1984, Fig. 16a) has given proof of the impact of the environmental change, since settlements would have moved in relation to water availability.

This hypothesis also provided an explanation for the arrival of the "Andronovo" populations from the North, who occupied lands largely abandoned by the local populations due to the decrease in irrigation and the advancing desert (Cattani et al. 2008; Cerasetti 2012). All in all, a drying climate variation at the beginning of the 4th millennium BP could have been responsible for the "collapse" of the urban system of the Oxus civilization.

By contrast, other scholars (Cremaschi 1998; Gerasimov 1978; Khlopina 1972; Lewis 1966; Lisitsyna 1978, 1981) disagree on major environmental modifications at the turn of the 5th and the 4th millennium BP. They assert that environmental dynamics linked to water supplies were not limited to the question of climate and waterfalls, but were the combination of several factors, such as geomorphological and geological events (Gerasimov 1978; Fouache et al. 2012).

Nevertheless, these previous assumptions are still based on few solid studies, not only concerning climate evolution and the specific ecological system of southern Central Asia, but also the duration of the settlements as well as water management in prehistory. All these issues require more long-term field investigation. 


\subsection{The Palaeoclimate Data}

Yet, the compilation of current data available on environmental changes already contributes towards better tackling the issue of the evolution of the environment and its impact on human groups in southern Central Asia during the Bronze Age.

Palaeoclimate studies in Eurasia are increasing in number in recent years. The synthesis of palaeoclimate records in Arid Central Asia from the Caspian Sea borders to Mongolia (Chen et al. 2008) reveals global tendencies, with a dry climate in the early Holocene (until ca. $8000 \mathrm{BP}$ ), followed by maximum-moisture conditions in the Mid-Holocene (ca. 8000-4000 BP), before decreasing moisture in the Late Holocene (4000 BP to the present day). Another synthesis of data from Central Asia (Wang et al. 2010) points at the differential evolution of the regions influenced or not by the two Asian Summer Monsoon sub-systems. In the Indian Summer Monsoon area, an increase of moisture levels and temperatures has been identified at around 10,000 until 8000 BP (Holocene Optimum), followed by drier and colder conditions until the Late Holocene. In the area outside of the present monsoon boundary, this decrease appears around $7500 \mathrm{BP}$-although interrupted by a wet period between 5000 and 2000 BP, whereas it appears by 6500 BP in the Indian Summer Monsoon area. However, the studies do not discuss potential abrupt changes during the different phases of the Holocene.

In that regard, another examination of records on world distribution (Mayewski et al. 2004) concludes several climate-change events during the Holocene, with rapid shifts marked by low latitude drought in 6000-5000, 4200-3800 and 3500-2500 BP, among others. Although no records correspond to Central Asia, a global aridification seemed to occur around 4200/3750 BP, known as the $4.2 \mathrm{ka}$ BP aridification event. This "megadrought brought a 30-50 percent reduction in precipitation and cooling across the Mediterranean, west to east, and across West Asia, Central Asia, Africa and the western hemisphere, as expressed in marine, lake, speleothem, glacial core, and tree-ring records" (Weiss 2017: 13).

In central Asia, Palaeoclimate studies particularly investigated the relationships between the atmospheric circulation and high-mountain environments through alpine and subalpine lake records (Beer et al. 2007; Heinecke et al. 2016; Lauterbach et al. 2014; Mischke et al. 2010; Ricketts et al. 2001). These studies infer the decrease of the influence of the Monsoon and the dominance of the Westerlies, bringing arid conditions during the second half of the Mid-Holocene to the present. At the lake Issyk Kul in Kyrghystan, Ricketts et al. (2001) identified a change in the climatic condition of the basin around $6900 \mathrm{BP}$ (transition from a fresh-water open-basin, well-mixed system to a closed-basin, more saline and relatively poorly mixed system) related to increasing aridity and atmospheric changes, diagnosed as the strengthening of the Siberian High, or the weakening of the Southwest Asian Low (Indian monsoon). The development of the Lake Karakul in Tajikistan marked by a reduction of the lake levels from $6600 \mathrm{BP}$ suggests a similar aridification of the climate (Heinecke et al. 2016). Later, from 4200 to $3500 \mathrm{BP}$, a high water level resulting from an intake from the melting of glaciers, snow fields and frozen grounds indicates warm climatic conditions, 
whereas subsequently (3500-1600 BP), a rapid cooling and a lower water level has been reconstructed (Mischke et al. 2010). In parallel, studies of palaeolimnology has reconstructed a cooling, a decrease of the water level and a glacier advance connected with precipitation surplus between 4200 and 3000 BP (Taft et al. 2014). Multi-proxy analyses at the lake Son Kol in Kyrgyzstan (Lauterbach et al. 2014) also confirm relatively wet climate conditions during the Mid-Holocene (between ca. 6000 and $5000 \mathrm{BP}$ ), followed by a drying between 4950 and $3900 \mathrm{BP}$, a return to more humid conditions around ca. $3900 \mathrm{BP}$, and then a moderate drying trend until present times. Alternatively, the study of vegetation and lacustrine development at the sub-alpine lake Kichikol in Kyrgyzstan (Beer et al. 2007) reveals a progressive increase in humidity with two stages of rise of the water table at ca. $5000 \mathrm{BP}$ and 4000 BP, which has also been interpreted as the weakening of the Central Asian High and Indian monsoon systems and the increase of westerly moisture transport from the Mediterranean region. Around $4000 \mathrm{BP}$, contradictory events have been identified: the increase of water level (suggesting more rainfall or a high meltwater inflow), and the marked decrease in pollen of Juniperus. The authors suggest the diminution of Juniperus forests, previously dense, may be related to other causes such as local effects of climatic changes. Later, from 4000 to $90 \mathrm{BP}$, climatic conditions are described as rather stable.

Outside mountains area, the study related to the sea-level of the Caspian Sea at the southeastern coast in Iran (Kakroodi et al. 2012) indicates a rapid rise of the water level between around 5000 and $2300 \mathrm{BP}$, which does not call for a climatic aridification. Lastly, peripheral data from Kazakhstan at the southern border of western Siberia (Kremenetski 1997; Kremenetski et al. 1997) show a drier continental climate in the area between around 4500 and 3600 BP, with certain stability in the period.

In short, beside the absence of clear abrupt dry episode at the beginning of the 4th millennium BP, the recent studies demonstrate the spatial variability and complexity of the climate system in Central Asia, ${ }^{3}$ as well as the sensitivity of the environment and the diversity of natural responses to climate change locally.

According to palynological studies made in the Aral Sea (Sorrel et al. 2007) and the similarities between records from central Asia and from the Near East (Cheng et al. 2012), central Asian climate can be viewed as integrated in the eastern Mediterranean system (Fouache et al. 2012, 2016). Palaeoclimatic data from this area may thus be also broadly meaningful of the conditions in Central Asia. They indicate a progressive increase in aridity in the second half of the 5th millennium BP (Courty and Weiss 1997; Kuzucuoğlu 2007). Two periods of dryness have been recorded (4200-4100 BP and 4050-3850 BP) separated by a half century more humid. This drying phase seemed to stop around $3850 \mathrm{BP}$ to be followed by a period of low humidity and relatively stable between 3850 and $2950 \mathrm{BP}$. The study of the speleothems of the

\footnotetext{
${ }^{3}$ Mischke et al. (2010: 10) point at "significant spatial differences in Holocene climate history between specific regions [...], and a complex Holocene climate heterogeneity within specific regions [...]. However, the number of Holocene climate records is still low in many regions of Central Asia and not sufficient to allow discussion and comparison of regional patterns of climate history".
} 
Soreq cave in Israel (Bar-Matthews and Ayalon 2011; Bar-Matthews et al. 1997) also indicates that, from $7000 \mathrm{BP}$ onwards the general climatic conditions became closer to the present conditions with several dry events, one of which fits between 4200 and 4050 BP. The analysis of the soils of the Van Lake, Turkey (Lemcke and Sturm 1997) illustrates a climatic change towards a more continental climate (decrease of the water level and of the humidity) between 4190 and 3040 BP.

Farther to the East also the synthesis of palaeoclimatic studies carried out in the Indian subcontinent (Madella and Fuller 2005)—with the aim to explain the "collapse" of the Indus civilization-concludes an aridification during the last centuries of the 5th millennium BP in the area of the Indus valley.

To sum up, even though Central Asian records are still patchy (Fig. 14.1) and more local and detailed palaeoclimatic studies from southern central Asia are lacking, the current data tend to demonstrate a globally wetter climate during the Mid-Holocene with several rapid changes. Considering the period of duration of the Oxus civilization (ca. 4250-3350 BP), a climatic aridity in the late 5th millennium BP is attested in different areas of the world, while the following first half of the 4th millennium BP would have been a period of relative climatic stability.

\subsection{Geomorphological Studies}

Recent geomorphological studies from southern Central Asia also largely contribute to the understanding of the Human-Environment interaction. They have been mostly carried out in the ecological niches of low or high river plains (Fig. 14.1). In the Murghab alluvial fan presently in the Karakum desert (central Turkmenistan), the work done by M. Cremaschi (1998) on different palaeochannels assumes very different climatic conditions than the present day, with a more important water supply until the 4th millennium BP. Accordingly, the Murghab would have been a fertile alluvial plain and the hydrological system near Bronze Age sites (Gonur Depe and Takhirbaj) were active until the end of the Bronze Age, i.e. the middle of the 4th millennium BP. Thus, these data suggest that there were no major changes in water sources during the period discussed here. Other fluvial geomorphological studies have been made in Afghanistan and Uzbekistan (Fouache et al. 2012, 2016). The examination of the palaeochannels of the Balkh River and the river Zerafshan reveals the strong dynamic of the hydrographical system with an extreme mobility of channels, a large range of movements and a great number of changes. This constant dynamic is created by classic avulsion processes, due to neotectonic deformations and the intensity of the flow. In parallel, the displacement of human settlements over the past 10,000 years has been recorded according to these changes. In northern Afghanistan, the persistency of occupation northwest of the plain (Dashly area) has been observed from the Bronze Age to Achaemenid times, suggesting a constant water availability. By contrast, in Iran (Fouache et al. 2013), around the site of Sabzevar (Khorasan), another evolution in the location of sites according to the water sources has been observed. Initially located along a river course or at the end of a natural channel during the Chalcolithic and early Bronze Age periods, sites progressively moved according to 
water availability, which suggests that water was less abundant. This evolution seems to occur during the chronological range between 4450 and $3850 \mathrm{BP}$. Lastly, around the Aral Sea, significant changes in moisture conditions have been reconstructed through the study of the water level from the archaeological data (Boroffka 2010; Boroffka et al. 2006). The authors reveal a shift in the course of the Amu-Darya River and the rise of water in the Sea around 3950 BP without substantial change in the next centuries.

In short, these environmental analyses carried out in Central Asia and northern Iran mostly record a permanency in occupation patterns and water availability, or coincide with those climatic data which identify a climate variation at the end of the 5th millennium BP.

\subsection{Discussion}

\subsubsection{A Present Lack of Correlation Between the Environmental Data and the Sociocultural Evolution}

All in all, the present palaeoenvironmental data, resulted from palaeoclimatic (Fig. 14.4) and geomorphological studies, do not allow us to correlate the progressive disappearance of the Oxus civilization during the first half of the 4th millennium BP with a climatic event.

These facts, however, do not mean that environmental dynamics did not contribute to the final evolution of the Oxus civilization. The study of climate history still requires special attention and clarification. ${ }^{4}$ Climatic changes can be long-term phenomena, which may not be immediately noticeable. Consequences from more local changes must be evidenced as well (Wilkinson 2003). Climate phenomena may be limited to specific, sometimes small, areas. Environmental effects of climatic changes can vary according to the degree of sensitivity of the geographical area and to the different hydrogeological contexts. The same event may not have the same impact according to the microscales. Numerous issues need to be further investigated, such as the reaction of the different geographical features to climate change or conversely the impact of changes in the ecological milieu on local/global climate (Dallmeyer and Claussen 2011; Heinecke et al. 2016).

Besides, the natural factors, in particular tectonic movements and cataclysms such as earthquakes, sea quakes, storms, etc., may also have played a significant role in local disturbances (Fouache 2013). Although this area records a high level of seismicity, until now very limited studies are involved in highlighting such disruptions

\footnotetext{
4"The previous climate, as the most important agent influencing the alteration of all other parts of an environment, is the subject of many scientific disciplines, although the outcomes are, despite tremendous efforts, still somewhat unsatisfactory. The main reasons for this are: the complexity of the climate system as such, the regionality of the climate, the short history of its direct instrumental measurement, the evaluation of the climatic parameters in relative terms (e.g. wetter, drier), the varying sensitivities of the proxies, and the difficulties of their more precise dating" (Dreslerová 2012: 43).
} 


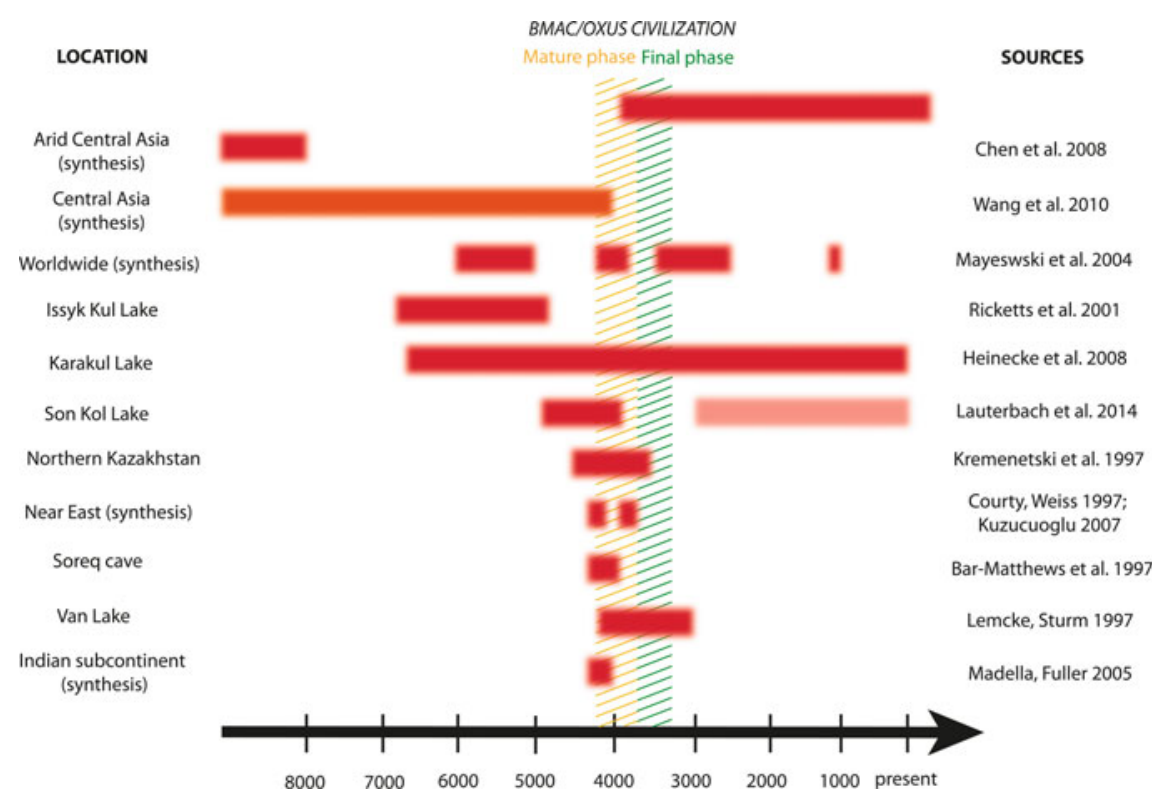

Fig. 14.4 Schematic graph of the records mentioning drier periods during the Mid- and Late Holocene in Central Asia and Middle East

(Berberian and Yeats 2001; Hollingsworth et al. 2010). However, if seismic activity may potentially explained some abandonment of settlements, local destructions are likely not sufficient to trigger a long-lasting sociocultural evolution, such as the transformation of the Oxus civilization which mirrors a plurality of changes.

\subsubsection{Resilience and Adaptations of the Populations to Climate Variation}

The impact of environmental changes differs according to the subsistence economy, the organisation of urban/rural relation, the settlement pattern and the size and type of archaeological sites, which are highly variable and for which correlations are still not clearly identified. Indeed, climatic change does not always imply a crisis situation. Cases of the independence of prehistoric societies when confronted with climatic conditions are known (Magny et al. 2008; Müller 2015). The difficulty of the study is to correlate the climate scale with the human scale too. Climate changes are not brutal phenomena, but rather an evolution, which suggests possibilities of adaptation to the events (Gregoricka 2016; McAnany and Yoffee 2009; Miller et al. 2011; Petrie et al. 2017). Populations often possess the capacity to adapt to changes, which depends upon the production system, the social organization and the interests of the different social groups (Rosen 2007: 148-149; Sala 2014). "Social and technological 
resilience versus resistance to change can be critical factors in the ability of societies to adapt to new environmental conditions. Resilience may vary between segments of society leading to greater resistance to change among those members of society leading to greater resistance to change among those members of society who benefit from current conditions" (Rosen 2007: 173).

Broadly speaking, resilience to climatic modifications can take several forms (Binford et al. 1997; Rosen 1997, 2007; Sala 2014; Weniger 2012): (1) the move and/or the dispersion of the population towards areas less affected by climatic modifications (new ecological areas); (2) an economic adaptation by a change in the economic strategy or by a technological adaptation to increase the production and/or the efficiency of storage to minimize the risks of shortages. Climatic change can also be a factor of technological innovations in order to compensate difficulties and to maintain a certain threshold of vital yields for the whole population, such as the adaptation of irrigation techniques or actions on cultivated plants (transformations of the plants known, new distribution of the different cultivated plants, etc.). Yet, during the Final Bronze Age in southern Central Asia, both phenomena occurred.

The movements of Bronze Age populations from North to South in the Murghab area according to the retraction of the alluvial fan have been suggested (Hiebert 1994; Sarianidi 1981, 1990). First, climatic and archaeological data must correspond in order to confirm such displacement was due to climatic reasons. Second, it should be acknowledged that, according to the proposed periodization, the populations would have already moved since the beginning of the Bronze Age occupation in this area, attested in the north-western area around Kelleli (Masimov 1981), dated at least to the Namazga IV period (ca. 4950-4450 BP). Especially considering the possible consequences of the $4.2 \mathrm{ka} \mathrm{BP}$ event, there is a priori no reason to suppose the inefficiency of the "displacement strategy" during the first half of the 4th millennium $\mathrm{BP}$, unless other factors occurred at the same time.

In any case, the one-time occupation of the sites in the Murghab has been definitely rejected (Luneau 2014; Salvatori 1998, 2008). The long chronological range of different sites, such as Gonur Depe (Jungner 2007) or Adzhi Kui (Rossi-Osmida 2007), whose occupation may have started at the end of the 6 th/beginning of the 5th millennium BP until the Final Bronze Age, is now well attested. The settlement pattern in the Murghab alluvial fan appears more complex than previously supposed, with a wider distribution of multi-period sites during the whole Bronze Age and a better geographical stability of sites. The data suggest that "the settlement system of Margiana during the Bronze Age had not been generated or conditioned by an environmental situation [...], but by spatial rules connected to human group dynamics and by the structural complexity of the political and administrative forms of the territory" (Salvatori 2008: 62). The effect of water availability for the duration of Bronze Age sites in the Murghab alluvial fan, and the systematic displacement of sites (according to the water availability) during the Bronze Age must still be demonstrated too, according to a detailed chronology in many areas. It is unlikely that a site persisted without a water supply in the vicinity, unless a larger more sophisticated irrigation network was expanded, and this does not seem to be the case according to the current data. 
Another example of the dispersion of Final Bronze Age populations is the increase in sites dated to this period only in the foothills in Tajikistan (Vinogradova 2004), where the environmental conditions do not necessarily require supplementary water intake. In Iran as well, Bronze Age populations adapted to the decrease in water resources by changing location (Fouache et al. 2013).

This adaptation to new ecological conditions also demonstrates the capacity of socioeconomic transformation of society. A reorganization of the ratios agriculture and herding in a subsistence economy in favour of an increase of herding with " $a$ supplementary exploitation of marginal areas by a lighter agro-pastoralism of steppe type, but without reducing nor the productive capacity, nor the demography of the sites related to the Oxus tradition"5 (Francfort and Lecomte 2002: 646) has also been suggested. In southern Uzbekistan, for instance, the evolution observed at the end of the Bronze Age has been interpreted as an "adaptation to an environment in which the sole irrigated agriculture is not the most suitable mode of exploitation"6 (Stride 2004: 280). The intensification of pastoralism would represent a real economic alternative required by the installation of populations in the foothills areas and the exploitation of diverse ecological areas which can be viewed as a flexible strategy. Along the Kopet Dagh range as well, P.M. Dolukhanov (1981) interpreted the deposits of silts between different layers at several sites as the result of repeated mud flows implied by the deforestation of the mountain slopes or by the increase of herding in the foothills.

Considering the improvement of farming practices, the current state of research on irrigation evokes the high dependency of Bronze Age populations upon the proximity of an active channel. Actual irrigated systems are still not proven in the different areas of the Oxus civilization. But in some regions, like in northern Afghanistan, ever since the Bronze Age populations succeeded in developing sophisticated techniques of control and regulation of water, demonstrating direct actions on the environment. For instance, even though this is yet to be proven for the Bronze Age, in the Balkh area the former riverbeds abandoned during the successive defluviations were used as irrigation canals, indicating high technological skills of the ancient population to control the hydraulic flow (Fouache et al. 2012). Likewise, the study of the spatial relationship of sites to water in the Murghab alluvial fan between the Late Bronze Age and the Early Iron Age (Rouse and Cerasetti 2015) indicates an increase of the average distance for the Early Iron Age sites in comparison to the Late/Final Bronze Age sites, which might be related to the use of more advanced hydraulic technology in the second half of the 4th millennium BP.

\footnotetext{
${ }^{5}$ Original quotation: "une mise en exploitation complémentaire des zones marginales par un agropastoralisme plus léger de type steppique, mais sans que ne soient en rien diminuées ni la capacité productive ni la démographie des sites de la tradition de l'Oxus".

${ }^{6}$ Original quotation: “adaptation à un environnement dans lequel l'agriculture irriguée seule n'est pas le mode d'exploitation le mieux adapté".
} 
Further, the possible intensification ${ }^{7}$ of the cultivation of millet in the area during the 4th millennium BP has been discussed, in particular regarding the connection with mobile populations and the exchanges over large distances in Eurasia (Miller et al. 2016; Spengler 2015). This plant is viewed as better adapted to dryness, and it may have been cultivated more with respect to an aridification. However, millet cultivation could also be linked to other reasons: the wish to increase the yields, an adaptation to the ecological environment of some specific sites, especially in the foothills, an adaptation of the agricultural practices to a possible decrease in irrigation, or a cultural choice influenced by other population groups, such as mobile populations coming from the North. ${ }^{8}$ In other areas, like in the Indus Civilization, millet could have been part of a strategy for the exploitation of new ecological areas, and it would have reduced the dependency on the winter cultures and ensured food supplements (Meadow 1993). These agricultural changes could have contributed to the decline of the urban Harappan civilization, according to some scholars (Madella and Fuller 2005). In the case of the Oxus civilization, it is possible, too, that changes of the agricultural strategies on a local scale towards a more diversified and extensive agriculture may have contributed to social changes, implying a possible restructuration of the urban social system.

\subsubsection{Convergence of Multiple Causes}

These reflexions also go towards new perspectives of research that consider the sociocultural transformations of the Oxus civilization around $3750 \mathrm{BP}$. The hypothesis of a single cause, especially climatic, is likely not the most appropriate. The synchronism between long and one-time events, climatic and sociocultural, always seems difficult to state and hazardous (Roberts et al. 2011). Sociocultural evolutions are expected to be more complex than simplistic hypotheses; they can result from multiple causes by the combination of different events, which are not necessarily solely environmental (Butzer 2012; Butzer and Endfield 2012; Knapp and Manning 2016). It should be reminded that changes at the end of the Bronze Age in southern central Asia did not only affect the settlement pattern and the subsistence economy, but also the ideology, the funeral strategy and the relations with neighbouring societies. Populations of the Oxus civilization at that time were faced with important transformations related to interregional exchanges (Luneau 2016) and cohabitation with mobile populations in the territory of the Oxus civilization (Cerasetti 2012;

\footnotetext{
${ }^{7}$ In archaeological literature the presence of millet is mentioned at several sites chronologically dated prior to the Final Bronze Age in southern Central Asia, such as Shortughaï from the Period I, Level II (Francfort et al. 1989: 175-185), which is currently dated to the end of the 5th millennium BP (Francfort 2016) or, possibly at Sapallitepe dated to the beginning of the 4th millennium BP (Askarov 1973: 133), and becoming more frequent in the latest levels dated to the Final Bronze Age, especially in campsites of mobile populations (3650-3450 BP).

${ }^{8}$ Archaeobotanical studies recently put forward the role of mobile pastoralists in the dispersion of crops, particularly millet (Spengler et al. 2014).
} 
Kuz'mina 2007; Luneau 2014, 2017; Rouse and Cerasetti 2018; Vinogradova and Kuz'mina 1996). The understanding of the convergence of these events is a wider topic of research.

\subsection{Conclusion}

The palaeoclimatic data available with reference to the Mid- to Late Holocene in Central Asia indicate so far a general wetter climate than the preceding Early Holocene with different events of rapid climate changes. In particular, the well-attested $4.2 \mathrm{ka}$ BP aridification event may have been also effective in Central Asia, which suggests that the early period of the Oxus civilization was faced with an aridity, whereas the last phase (ca. 3750-3350 BP) could have been a period of relative climatic stability. The absence of a clear coincidence between specific climatic events and the "collapse" of the Oxus civilization can be inferred, as far as now.

On the contrary, the palaeoclimatic data raise questions about the consequences of an aridification at the beginning of the Oxus civilization. How and to what degree? Was the rise of the Oxus civilization linked to water management (water availability, improvement of irrigation techniques, etc.)? The climate aridity in the area at the end of the 5th millennium BP asserts the ability of the populations to maintain a high agricultural and economic potential for the development of the society and particularly challenge on the nature and degree of dependence of the subsistence system on irrigated cultivation. The relationship between irrigation and the state as well as the model of hydraulic societies as asserted by K.A. Wittfogel (1957) have been rightly criticized (see Francfort et al. 1989; Stride et al. 2009 for instance) because of the existence of complex societies without large-scale irrigation or conversely, the practice of large-scale irrigations by small independent communities. Further research on the link between water management and the development of the Oxus Civilization will be particularly relevant.

Indeed, the Human-Environment relationship in the past, as in the present, is a complex process, which can have highly various impacts on both human society and ecology in regard to the local situation. Environmental changes and events may not be a factor of human innovation and cultural evolution (Roberts et al. 2016), just as they may also create significant vulnerability and disruptions in human actions (Manning et al. 2017).

Hence, the challenge relies upon the identification of the impacts of climate variations on local natural resources, flora and fauna and of the societies that depended upon this environment. "A key focus for understanding the impact of climate on humans is now to create a record that reflects local climate at high temporal and spatial resolution across an entire landscape" (d'Alpoim Guedes et al. 2016: 3). Multi-scalar research is needed for increasing more precise archaeological records on social shifts and on the Holocene climate variability in Central Asia, according to regional and micro-regional analyses and related to a robust and detailed chronology (Butzer 2012; Dearing 2006; Sala 2014). The temporal uncertainty does not allow 
us currently to provide an adequate temporal and spatial climatic reconstruction of the climate and constitutes a primary target for future research. The review of environmental studies on Central Asian prehistory also reveals that the fluvial dynamics, which can have different explanations, should not be the only field in study to consider the human socio-spatial evolution. Different fields in research (geography, geology, anthropology, ecology, isotopes, etc.) must be exploited in order to make statements about the Holocene climate variability in Central Asia and the local impact on the environment and on human communities (settlement pattern and sociocultural transformations, coevolution of the fauna and the flora in specific environments, etc.). Simultaneously, anthropic factors are crucial for sociocultural mutations (whatever the environmental conditions). The capacity of anthropogenic changes (deforestation, desertification, salinization, woodland management, etc.) and of adaptation of human groups, according to phenomena that are currently underestimated (such as flexible economic exploitation of different ecosystems, actions on plants and animals, etc.) is still a large field to explore in the human-environment dynamics in prehistoric Central Asia. It is necessary to take the complexity of human interactions with the ecosystem into account, as suggested by the niche construction approach (Spengler 2014). The simulation of the interactions between social and natural forces through modelling (Butzer and Endfield 2012; Sala 2014) also provides now a major support for the understanding of the long-term socio-natural systems in Eurasia.

Acknowledgements I would like to express my gratitude to Professor Eric Fouache (University Sorbonne Abu Dhabi) for his remarks and suggestions for reading, and I also warmly thank the anonymous reviewers for their highly helpful and valuable comments.

\section{References}

Aishan, T., Halik, U., Kurban, A., Cyffka, B., Kuba, M., Betz, F., et al. (2015). Eco-morphological response of floodplain forests (Populus euphratica Oliv.) to water diversion in the lower Tarim River, northwest China. Environmental Earth Science, 73(2), 533-545.

Askarov, A. A. (1973). Sapallitepa. Tashkent: Filiala Akademija Nauk.

Bar-Matthews, M., \& Ayalon, A. (2011). Mid-Holocene climate variations revealed by highresolution speleothem records from Soreq Cave, Israel and their correlation with cultural changes. The Holocene, 21(1), 163-171.

Bar-Matthews, M., Ayalon, A., \& Kaufman, A. (1997). Late quaternary paleoclimate in the Eastern Mediterranean region from stable isotope analysis of speleothems at Soreq Cave, Israel. Quaternary Research, 47(2), 155-168.

Beer, R., Heiri, O., \& Tinner, W. (2007). Vegetation history, fire history and lake development recorded for 6300 years by pollen, charcoal, loss on ignition and chironomids at a small lake in southern Kyrgyzstan (Alay Range, Central Asia). The Holocene, 17(7), 977-985.

Berberian, M., \& Yeats, R. S. (2001). Contribution of archaeological data to studies of earthquake history in the Iranian Plateau. Journal of Structural Geology, 23, 563-584.

Binford, M. W., Kolata, A. L., Brenner, M., Janusek, J. W., Seddon, M. T., Abbott, M., et al. (1997). Climate variation and the rise and fall of an Andean Civilization. Quaternary Research, 47, 235-248.

Boroffka, N. (2010). Archaeology and its relevance to climate and water level changes: A review. In A. G. Kostianoy \& A. N. Kosarev (Eds.), The aral sea environment (pp. 283-303). Berlin: Springer. 
Boroffka, N., Oberhänsli, H., Sorrel, P., Demory, F., Reinhardt, C., Wünnemann, B., et al. (2006). Archaeology and climate: Settlement and lake-level changes at the Aral Sea. Geoarchaeology, 21(7), 721-734.

Butzer, K. W. (2012). Collapse, environment, and society. PNAS, 109, 3632-3639.

Butzer, K. W., \& Endfield, G. H. (2012). Critical perspectives on historical collapse. PNAS, 109, 3628-3631.

Cattani, M. (2008). The final phase of the Bronze Age and the "Andronovo Question" in Margiana. In S. Salvatori \& M. Tosi (Eds.), The Bronze Age and Early Iron Age in the Margiana lowlands. Facts and methodological proposals for a redefinition of the research strategies. The archaeological map of the Murghab delta studies and reports (Vol. II, pp. 133-151). Oxford: Archaeopress.

Cattani, M., Cerasetti, B., Salvatori, S., \& Tosi, M. (2008). The Murghab Delta in Central Asia 1990-2001: The GIS from research source to a reasoning tool for the study of settlement change in long-term fluctuations. In S. Salvatori \& M. Tosi (Eds.), The Bronze Age and Early Iron Age in the Margiana lowlands: Facts and methodological proposals for a redefinition of the research strategies: The archaeological map of the Murghab delta studies and reports (Vol. II, pp. 39-45). Oxford: Archaeopress.

Cerasetti, B. (2012). Remote sensing and survey of the Murghab alluvial fan, southern Turkmenistan: The coexistence of nomadic herders and sedentary farmers in the late Bronze Age and early Iron Age. In R. Matthews, \& J. Curtis (eds.), Proceedings of the 7th International Congress on the Archaeology of the Ancient Near East, 12 April-16 April 2010 (Vol. 1, pp. 539-558). Wiesbaden: Harrassowitz Verlag.

Chen, F., Yu, Z., Yang, M., Ito, E., Wang, S., Madsen, D. B., et al. (2008). Holocene moisture evolution in arid central Asia and its out-of-phase relationship with Asian monsoon history. Quaternary Science Reviews, 27, 351-364.

Cheng, H., Zhang, P. Z., Spötl, C., Edwards, R. L., Cai, Y. J., Zhang, D. Z., et al. (2012). The climatic cyclicity in semiarid-arid central Asia over the past 500,000 years. Geophysical Research Letters, 39.

Cheng, H., Spötl, C., Breitenbach, S. F. M., Sinha, A., Wassenburg, J. A., Jochum, K. P., et al. (2016). Climate variations of Central Asia on orbital to millennial timescales. Scientific Reports, 6, 36975.

Courty, M.-A., \& Weiss, H. (1997). The scenario of environmental degradation in the Tell Leilan Regionb, Ne Syria, during the late third Millenium abrupt climate change. In H. N. Dalfes, G. Kukla, \& H. Weiss (Eds.), Third Millenium BC climate change and old world collapse (pp. 107-147). Berlin, Heidelberg: Springer.

Cremaschi, M. (1998). Palaeohydrography and middle holocene desertification in the Northern Fringe of the Murghab Delta. In A. Gubaev, G. A. Koshelenko, \& M. Tosi (Eds.), The archaeological map of the Murghab delta. Preliminary reports 1990-1995 (pp. 15-25). Roma: Istituto Italiano per l'Africa e l'Oriente.

Cullen, H. M., de Menocal, P. B., Hemming, S., Hemming, G., Brown, F. H., Guiderson, T., et al. (2000). Climate change and the collapse of the Akkadian Empire: Evidence from the deep sea. Geology, 28(4), 379-382.

d'Alpoim Guedes, J. A., Crabtree, S. A., Bocinky, R. K., \& Kohler, T. A. (2016). Twenty-first century approaches to ancient problems: Climate and society. PNAS, 113(51), 14483-14491.

Dalfes, H. N., Kukla, G., \& Weiss, H. (1997). Third Millenium BC climate change and old world collapse. Berlin, Heidelberg: Springer.

Dallmeyer, A., \& Claussen, M. (2011). The influence of land cover change in the Asian monsoon region on present-day and mid-Holocene climate. Biogeosciences, 8, 1499-1519.

De Pauw, E. (2007). Principal biomes of Central Asia. In R. Lal, M. Suleimenov, B. A. Stewart, D. O. Hansen, \& P. Doraiswamy (Eds.), Climate change and terrestrial carbon sequestration in Central Asia (pp. 3-24). London: Taylor\&Francis.

Dearing, J. (2006). Climate-human-environment interactions: Resolving our past. Climate of the Past, 2(2), 187-203.

deMenocal, P. B. (2001). Cultural responses to climate change during the late holocene. Science, 292, 667-673. 
Djamali, M., Brewer, S., Breckle, S. W., \& Jackson, S. T. (2012). Climatic determinism in phytogeographic regionalization: A test from the Irano-Turanian region, SW and Central Asia. Flora, 207, 237-249.

Dolukhanov, P. M. (1981). The ecological prerequisites for early farming in Southern Turkmenia. In P. L. Kohl (Ed.), The Bronze Age Civilization of Central Asia. Recent Soviet Discoveries (pp. 359-385). New York: M.E. Shape.

Dolukhanov, P. M. (1988). Paléoécologie de l'Asie centrale aux Ages de la Pierre et du Bronze. In J.-C. Gardin (Ed.), L'Asie centrale et ses rapports avec les civilisations orientales des origines à l'âge du Fer, Mémoires de la Mission Archéologique Française en Asie centrale (pp. 215-221). Paris: Editions de Boccard.

Dreslerová, D. (2012). Human response to potential robust climate change around $5500 \mathrm{cal}$ BP in the Territory of Bohemia (the Czech Republic). Interdisciplinaria Archaeologica Natural Sciences in Archaeology, III, 1, 43-55.

Fouache, E. (2013). Using the geo-archaeological approach to explain past urban hazards. In D. Serre, B. Barroca, \& R. Laganier (Eds.), Resilience and urban risk management (pp. 15-20). London: Taylor\&Francis Group.

Fouache, E., Besenval, R., Cosandey, C., Coussot, C., Ghilardi, M., Huot, S., et al. (2012). Paleochannels of the Balkh river (northern Afghanistan) and human occupation since the Bronze Age period. Journal of Archaeological Science, 39, 3415-3427.

Fouache, E., Francfort, H.-P., Cosandey, C., Adle, C., Bendezu-Sarmiento, J., \& Vahdati, A. A. (2013). Les régions de Bam et de Sabzevar (Iran): une évolution dans l'implantation des sites archéologiques et dans la gestion des ressources en eau compatible avec l'hypothèse d'une aridification croissante du climat entre 2500-1900 BC. In J. Bendezu-Sarmiento (Ed.), L'archéologie française en Asie centrale, Cahiers d'Asie centrale, 21-22 (pp. 559-572). Paris: Editions de Boccard.

Fouache, E., Rante, R., Mirzaakhmedov, D., Ragala, R., Dupays, M., Vella, C., et al. (2016). The role of catastrophic floods generated by collapse of natural dams since the neolithic in the Oases of Bukhara and Qaraqöl: Preliminary results. International Journal of Geohazards and Environment, 2(3), 150-165.

Frachetti, M., \& Rouse, L. M. (2012). Central Asia, the steppe and the Near East, 2500-1500 BC. In D. Potts (Ed.), Companion to the Archaeology of the Near East (pp. 687-705). London: Blackwell.

Francfort, H.-P. (2009). L'âge du Bronze en Asie centrale. La civilisation de l'Oxus. Anthropology of the Middle East, 4(1), 91-111.

Francfort, H.-P. (2016). How the twins met: Indus and Oxus Bronze Age civilizations in Eastern Bactria: Shortughaï revisited forty years later. In N. A. Dubova (Ed.), Trudy Margianskoj Arkheologicheskoj Ekspeditsii (pp. 461-475). Moskow: Starij Sad.

Francfort, H.-P., \& Lecomte, O. (2002). Irrigation et société en Asie centrale des origines à l'époque achéménide. Annales Histoire, Sciences Sociales, 57(3), 625-663.

Francfort, H.-P., Boisset, C., Buchet, L., Desse, J., Echallier, J.-C., Kermorvant, A., et al. (1989). Fouilles de Shortughaï: recherches sur l'Asie centrale protohistorique. Paris: Diffusion de Boccard.

Gentelle, P. (2001). Irrigations antiques en Bactriane du nord: l'image de satellite, la prospection archéologique, les inférences historiques. In P. Leriche, C. Pidaev, M. Gelin, \& K. Abdullaev (Eds.), La Bactriane au carrefour des routes et des civilisations d'Asie centrale. Termez et les villes de Bactriane-Tokharestan. Actes du colloque de Termez 1997 (pp. 163-172). Paris: Maisonneuve \& Larose-IFEAC.

Gerasimov, I. P. (1978). Ancient rivers in the deserts of Soviet Central Asia. In W. C. Brice (Ed.), The environmental history of the near and middle east since the Last Ice Age (pp. 319-334). London: Academic Press.

Gessner, U., Naeimi, V., Klein, I., Kuenzer, C., Klein, D., \& Dech, S. (2013). The relationship between precipitation anomalies and satellite-derived vegetation activity in Central Asia. Global and Planetary Change, 110(A), 74-87. 
Giosana, L., Clift, P. D., Macklinc, M. G., Fuller, D. Q., Constantinescue, S., Durcanc, J. A., et al. (2012). Fluvial landscapes of the Harappan civilization. Proceedings of the National Academy of Sciences of the United States of America, 109(26), 1688-1694.

Gregoricka, L. A. (2016). Human response to climate change during the Umm an-Nar/Wadi Suq transition in the United Arab Emirates. International Journal of Osteoarchaeology, 26, 211-220.

Haug, G. H., Ganthier, D., Peterson, L. C., Sigman, D. M., Hughen, Y. R., \& Aeschlimann, B. (2003). Climate and the collapse of Maya Civilization. Science, 299, 1731-1735.

Heinecke, L., Mischke, S., Adler, K., Barth, A., Biskaborn, B.K., Plessen, B., et al. (2016). Late pleistocene to Holocene climate and limnological changes at Lake Karakul (Pamir Mountains, Tajikistan). Climate of the Past Discussions, https://doi.org/10.5194/cp-2016-34.

Hiebert, F. T. (1994). Origins of the Bronze Age Oasis Civilization in Central Asia. Cambridge: Peabody Museum of Archaeological and Ethnological Harvard University.

Holdaway, S. J., Douglass, S. J., \& Fanning, P. C. (2013). A new ecological framework for understanding human-environment interactions in Arid Australia. In D. Frankel, J. M. Webb, \& S. Lawrence (Eds.), Archaeology in environment and technology: intersections and transformations (pp. 51-68). London: Routledge.

Hollingsworth, J., Nazari, H., Ritz, J.-F., Salamati, R., Talebian, M., Bahroudi, A., et al. (2010). Active tectonics of the east Alborz mountains, NE Iran: Rupture of the left-lateral Astaneh fault system during the great 856 A.D. Qumis earthquake. Journal of Geophysical Research, 115, https://doi.org/10.1029/2009jb007185.

Jungner, H. (2007). Radiocarbon dating of samples from the Necropolis of Gonur in Turkmenistan. In V. I. Sarianidi (Ed.), Necropolis of Gonur (pp. 338-339). Athens: Kapon Editions.

Kakroodi, A. A., Kroonenberg, S. B., Hoogendoorn, R. M., Mohammd Khani, H., Yamani, M., Ghassemi, M. R., et al. (2012). Rapid Holocene sea-level changes along the Iranian Caspian coast. Quaternary International, 263, 93-103.

Khlopina, L. I. (1972). Southern Turkmenia in the Late Bronze Age. East and West, 22(3-4), 199-214.

Kirch, P. V. (2005). Archaeology and global change: The holocene record. Annual Review of Environment and Resources, 30(1), 409-440.

Knapp, A. B., \& Manning, S. W. (2016). Crisis in context: The end of the Late Bronze Age in the Eastern Mediterranean. American Journal of Archaeology, 120(1), 99-149.

Kohl, P. L. (1984). Central Asia: Paleolithic beginnings to the Iron Age. Paris: Editions Recherche sur les Civilisations.

Kohl, P. L. (2007). The making of Bronze Age Eurasia. Cambridge: Cambridge University Press.

Koshelenko, G. A., Gubaev, A., Gaibov, V. A., \& Bader, A. (1994). Mervskij Oazis: dinamika sistem rasselenija i irrigatsii. Vestnik Drevnei Istorii, 4, 79-91.

Kremenetski, C. V. (1997). The Late Holocene environmental and climate shift in Russia and surrounding lands. In H. N. Dalfes, G. Kukla, \& H. Weiss (Eds.), Third Millenium BC climate change and old world collapse (pp. 351-370). Berlin, Heidelberg: Springer.

Kremenetski, C. V., Tarasov, P. E., \& Cherkinsky, A. E. (1997). Postglacial development of Kazakhstan pine forests. Géographie physique et Quaternaire, 51(3), 391-404.

Kuz'mina, E. E. (2007). The origin of the Indo-Iranians. Leiden: Brill.

Kuzucuoğlu, C. (2007). Climatic and environmental trends during the Third Millennium B.C. in Upper Mesopotamia. In C. Kuzucuoğlu, \& C. Marro (Eds.), Sociétés humaines et changement climatique à la fin du troisième millénaire: une crise a-t-elle eu lieu en Haute Mésopotamie? Actes du Colloque de Lyon, 5-8 décembre 2005 (pp. 459-480). Paris: De Boccard.

Kuzucuoğlu, C., \& Marro, C. (2007). Sociétés humaines et changement climatique à la fin du troisième millénaire: une crise a-t-elle eu lieu en Haute Mésopotamie? Actes du colloque de Lyon, 5-8 décembre 2005. Paris: De Boccard.

Lamberg-Karlovsky, C. C. (2012). The Oxus civilization (aka: the Bactria-Margiana archaeological complex). The Review of Archaeology, 30, 59-75.

Lauterbach, S., Witt, R., Plessen, B., Dulski, P., Prasad, S., Mingram, J., et al. (2014). Climatic imprint of the mid-latitude Westerlies in the Central Tian Shan of Kyrgyzstan and teleconnections to North Atlantic climate variability during the last 6000 years. The Holocene, 24(8), 970-984.

Lemcke, G., \& Sturm, M. (1997). $\delta 18$ O and trace element measurements as proxy for the reconstruction of climate changes at Lake Van (Turkey): Preliminary results. In H. N. Dalfes, G. Kukla, 
\& H. Weiss (Eds.), Third Millennium B.C. climate change and old world collapse (pp. 653-678). Berlin, Heidelberg: Springer.

Lewis, R. A. (1966). Early irrigation in West Turkestan. Annals of the Association of the American Geografers, 56(3), 467-491.

Lisitsyna, G. N. (1978). Stanovlenie i razvitie oroshaemogo zemledelija v juzhnoj Turkmenii. Moskow: Nauka.

Lisitsyna, G. N. (1981). The history of irrigation agriculture in southern Turkmenia. In P. L. Kohl (Ed.), The Bronze Age civilization in Central Asia. Recent discoveries (pp. 350-358). New York: M.E. Shape.

Ljapin, A. A. (1990). Paleogeografija del'ty Murgaba (bronzovij i zheleznij veka). Problemy Osvoenija Pustyn', 3, 57-65.

Luneau, É. (2014). La fin de la civilisation de l'Oxus. Transformations et recompositions des sociétés de l'âge du Bronze final en Asie centrale méridionale. Paris: De Boccard.

Luneau, É. (2015). A new assessment of the end of the Oxus Civilization (Southern Central Asia, ca. 1750-1500/1400 BCE): Overview of the transformations of the society. In G. Affanni, C. Baccarin, L. Cordera, A. Di Michele \& K. Gavagnin (Eds.), Broadening Horizons 4: Conference of young researchers working in the Ancient Near East, Egypt and Central Asia, University of Torino, October 2011 (pp. 303-308). Oxford: British Archaeological Reports.

Luneau, É. (2016). The fall of the Oxus civilization and the role of exchanges with the neighboring societies during the first half of the second Millennium B.C. In V. Lefèvre, A. Didier, \& B. Mutin (Eds.), South Asian Archaeology 2012, Man and environment in Prehistoric and Protohistoric South Asia: New Perspectives (Vol. 1, pp. 169-183). Turnhout: Brepols.

Luneau, É. (2017). Transfers and interactions between North and South in Central Asia during the Bronze Age. In F. Grenet, A. Vergati, J. Ebert, M.-K. Lang, \& C. Jahoda (Eds.), Interaction in the Himalayas and Central Asia, proceedings of the third international SEECHAC colloquium (pp. 13-27). Vienna: Austrian Academy of Sciences Press.

Luneau, É. (in press). The End of the Oxus Civilization. In B. Lyonnet \& N. Dubova (Eds.), The World of the Oxus Civilization. London: Routledge.

Lyonnet, B., \& Dubova, N. (in press). The World of the Oxus Civilization. London: Routledge.

Madella, M., \& Fuller, D. Q. (2005). Palaeoecology and the Harappan Civilisation of South Asia: A reconsideration. Quaternary Science Reviews, 25(11-12), 1283-1301.

Magny, M., Gauthier, E., Vannière, B., \& Peyron, O. (2008). Paleohydrological changes over the last millenium recorded at Lake Joux in the Jura Moutains, Switzerland. The Holocene, 18(2), 255-265.

Mannig, B., Müller, M., Starke, E., Merkenschlager, C., Mao, W., Zhi, X., et al. (2013). Dynamical downscaling of climate change in Central Asia. Global and Planetary Change, 110(A), 26-39.

Manning, J. G., Ludlow, F., Stine, A. R., Boos, W. R., Sigl, M., \& Marlon, J. R. (2017). Volcanic suppression of Nile summer flooding triggers revolt and constrains interstate conflict in ancient Egypt. Nature Communications, (p. 900).

Masimov, I. (1981). The study of the Bronze Age sites in the Lower Murghab. In P. L. Kohl (Ed.), The Bronze Age civilization in Central Asia. Recent discoveries (pp. 194-220). New York: M.E. Sharpe.

Mayewski, P. A., Rohling, E. E., Stager, J. C., Karlén, W., Maasch, K. A., Meeker, L. D., et al. (2004). Holocene climate variability. Quaternary Research, 62(3), 243-255.

McAnany, P. A., \& Yoffee, N. (2009). Questionning collapse. Human resilience, ecological vulnerability, and the aftermath of empire. Cambridge: Cambridge University Press.

Meadow, R. (1993). Continuity and change in the agriculture of the Greater Indus Valley. International Association for the Study of the Cultures of Central Asia Information Bulletin, 19, 63-77.

Miller, N. F., Moore, K. M., \& Ryan, K. (2011). Sustainable lifeways: Cultural persistence in an ever-changing environment. Philadelphia: University of Pennsylvania Museum of Archaeology and Anthropology.

Miller, N. F., Spengler, R. N., \& Frachetti, M. (2016). Millet cultivation across Eurasia: Origins, spread and the influence of seasonal climate. The Holocene, 26(10), 1566-1575. 
Mischke, S., Rajabov, I., Mustaeva, N., Zhang, C., Herzschuh, U., Boomer, I., et al. (2010). Modern hydrology and late Holocene history of Lake Karakul, Eastern Pamirs (Tajikistan): A reconnaissance study. Palaeogeography, Palaeoclimatology, Palaeoecology, 289, 10-24.

Morales, M., Barberena, R., Belardi, J. B., Borrero, L., Cortegoso, V., Durán, V., et al. (2009). Reviewing human-environment interactions in arid regions of southern South America during the past 3000 years. Palaeogeography, Palaeoclimatology, Palaeoecology, 281(3-4), 283-295.

Mousavi, A. (2008). Late Bronze Age in North-Eastern Iran: an alternative approach to persisting problems. Iran, XLVI, 105-120.

Mueller, L., Suleimenov, M., Karimov, A., Qadir, M., Saparov, A., Balgabayev, N., et al. (2014). Land and water resources of Central Asia, their utilisation and ecological status. In L. Mueller, A. Saparov, \& G. Lischeid (Eds.), Novel measurement and assessment tools for monitoring and management of land and water resources in agricultural landscapes of Central Asia (pp. 3-59). Heidelberg: Springer.

Müller, J. (2015). Crisis - what crisis? Innovation: Different approaches to climatic change around 2200 BC. In H. Meller, H. Wolfgang Arz, R. Jung, \& R. Risch (Eds.), 2200 BC-Ein Klimasturz als Ursache für den Zerfall der alten Welt? 7. Mitteldeutscher Archäologentag vom 23. bis 26. Oktober 2014 in Halle (Saale) (pp. 651-667). Haale: Landesamt für Denkmalpflege und Archäologie Sachsen-Anhalt.

P'jankova, L. T. (1994). Central Asia in the Bronze Age: Sedentary and nomadic cultures. Antiquity, 68, 355-372.

Petrie, C. A., Singh, R. N., Bates, J., Dixit, Y., French, C. A. I., Hodell, D. A., et al. (2017). Adaptation to variable environments, resilience to climate change. Investigating land, water and settlement in Indus Northwest India. Current Anthropology, 58.

Possehl, G. (2007). The Middle Asian interaction sphere. Trade and contact in the 3rd Millenium BC. Expedition, 49(1), 40-42.

Ricketts, R. D., Johnson, T. C., Brown, E. T., Rasmussen, K. A., \& Romanovsky, V. V. (2001). The Holocene paleolimnology of Lake Issyk-Kul, Kyrgyzstan: Trace element and stable isotope composition of ostracodes. Palaeogeography, Palaeoclimatology, Palaeoecology, 176(1), 207-227.

Roberts, N., Eastwood, W. J., Kuzucuoğlu, C., Fiorentino, G., \& Caracuta, V. (2011). Climatic, vegetation and cultural change in the eastern Mediterranean during the mid-Holocene environmental transition. The Holocene, 21(1), 147-162.

Roberts, P., Henshilwood, C. S., van Niekerk, K. L., Keene, P., Gledhill, A., Reynard, J., et al. (2016). Climate, environment and early human innovation: Stable isotope and faunal proxy evidence from archaeological sites (98-59 ka) in the Southern Cape, South Africa. Plos One, 11(7), e0157408.

Rosen, A. M. (1997). Environmental change and human adaptational failure at the end of the early Bronze Age in the Southern Levant. In H. N. Dalfes, G. Kukla, \& H. Weiss (Eds.), Third Millenium $B C$ climate change and old world collapse (pp. 25-38). Berlin, Heidelberg: Springer.

Rosen, A. M. (2007). Civilizing climate: Social responses to climate change in the ancient near east. Plymouth: AltaMira Press.

Rossi-Osmida, G. (2007). Adzhi Kui Oasis. La citadella delle statuette. Venizia: Il Punto Edizioni.

Rouse, L., \& Cerasetti, B. (2015). Micro-dynamics and macro-patterns: Exploring new archaeological data for the late Holocene human-water relationship in the Murghab alluvial fan, Turkmenistan. Quaternary International, 437, 20-34.

Rouse, L., \& Cerasetti, B. (2018). Mixing metaphors - sedentary-mobile interactions and localglobal connections in prehistoric Turkmenistan. Antiquity, 92(363), 674-689.

Sala, R. (2014). Methodological problems concerning the correlation between plaeoclimatic and archaeological data. In C.C. Lamberg-Karlovsky, B. Genito, \& B. Cerasetti (Eds.), My Life is like the Summer Rose. Maurizio Tosi e l'Archeologia como modo di vivere. Papers in honour of Maurizio Tosi for his 70th birthday (pp. 677-684). Oxford: British Archaeological Reports International Series 2690.

Salvatori, S. (1998). Margiana archaeological map: The Bronze Age settlement pattern. In A. Gubaev, G. A. Koshelenko, \& M. Tosi (Eds.), The archaeological map of the Murghab delta. Preliminary reports 1990-1995 (pp. 57-65). Roma: Istituto Italiano per l'Africa e l'Oriente. 
Salvatori, S. (2008). The Margiana settlement pattern from the Middle Bronze Age to the ParthianSasanian: A contribution to the study of complexity. In S. Salvatori, \& M. Tosi (Eds.), The Bronze Age and Early Iron Age in the Margiana Lowlands. Facts and Methodological Proposals for A Redefinition of the Research Strategies. The Archaeological Map of the Murghab Delta Studies and Reports vol. II (pp. 57-74) Oxford: Archaeopress.

Sarianidi, V. I. (1981). Margiana in the Bronze Age. In P. L. Kohl (Ed.), The Bronze Age civilization in Central Asia: Recent discoveries (pp. 165-193). New-York: M.E. Sharpe.

Sarianidi, V. I. (1990). Drevnosti strany Margush. Ashkhabad: Ylym.

Sorrel, P., Popescu, S.-M., Klotz, S., Suc, J.-P., \& Oberhansli, H. (2007). Climate variability in the Aral Sea basin (Central Asia) during the late Holocene base on vegetation changes. Quaternary Research, 67, 357-370.

Spengler, R. (2014). Niche dwelling vs. niche construction: Landscape modification in the Bronze and Iron Ages of Central Asia. Human Ecology, 42(6), 813-821.

Spengler, R. (2015). Agriculture in the Central Asian Bronze Age. World Prehistory, 28, 215-253.

Spengler, R., Frachetti, M., Doumani, P., Rouse, L., Cerasetti, B., Bullion, E., \& Mar'yashev, A. (2014). Early agriculture and crop transmission among Bronze Age mobile pastoralists of Central Eurasia. Proceedings of the Royal Society B, 281.

Stride, S. (2004). Géographie archéologique de la province du Surkhan Darya (Ouzbékistan du sud/Bactriane du nord) (Thèse de doctorat (unpublished)). Université Paris I, Paris.

Stride, S., Rondelli, B., \& Mantellini, S. (2009). Canals versus horses: Political power in the oasis of Samarkand. World Archaeology, 41(1), 73-87.

Taft, L., Mischke, S., Wiechert, U., Leipe, C., Rajabov, I., \& Riedel, F. (2014). Sclerochronological oxygen and carbon isotope ratios in Radix (Gastropoda) shells indicate changes of glacial meltwater flux and temperature since 4,200 cal yr BP at Lake Karakul, eastern Pamirs (Tajikistan). Journal of Paleolimnology.

Vinogradov, A. V., \& Mamedov, E. D. (1974). Landshaftno-klimaticheskie uslovija sredneaziatskikh pustyn' v golotsene. Istorija Material'naja Kultury Uzbekistana, 11, 32-44.

Vinogradova, N. M. (2004). Jugo-zapadnyj Tadzhikistan v epokhu pozdnej bronzy. Moscow: Institut Vostokovedenija - Rossijskaja Akademija Nauk.

Vinogradova, N. M. \& Kuz'mina, E. E. (1996). Contacts between the Steppe and Agricultural Tribes of Central Asia in the Bronze Age. In F. T. Hiebert, \& N. Di Cosmo (Eds.), Between Lapis and Jade. Ancient Cultures of Central Asia, Anthropology and Archaeology of Eurasia (pp. 29-54). New-York: Sharpe.

Walker, M. J. C., Berkelhammer, M., Björck, S., Cwynar, L. C., Fisher, D. A., Long, A. J., et al. (2012). Formal subdivision of the Holocene Series/Epoch: A discussion paper by a working group of INTIMATE (integration of ice-core, marine and terrestrial records) and the subcommission on quaternary stratigraphy (international commission on stratigraphy). Journal of Quaternary Science, 27(7), 649-659.

Wang, Y., Liu, X., \& Herzschuh, U. (2010). Asynchronous evolution of the Indian and East Asian Summer Monsoon indicated by Holocene moisture patterns in monsoonal central Asia. EarthScience Reviews, 103, 135-153.

Weiss, H. (2017). Megadrought and Collapse. New York: Oxford University Press.

Weiss, H., \& Courty, M.-A. (1993). The genesis and collapse of the Akkadian Empire: The accidental refraction of historical law. In M. Liverani (Ed.), Akkad the first world empire: Structure, ideology, traditions (pp. 131-155). Padova: Sargon.

Weninger, B. (2012). Réponse culturelle aux changements climatiques rapides de l'Holocène en Méditerranée orientale. In J.-F. Berger (Ed.), Des climats et des hommes (pp. 171-184). Paris: La Découverte.

Wilkinson, T. J. (2003). Archaeological landscapes of the near east. Tucson: The University of Arizona Press.

Wittfogel, K. (1957). Oriental despotism; a comparative study of total power. New York: Random House. 
Open Access This chapter is licensed under the terms of the Creative Commons Attribution 4.0 International License (http://creativecommons.org/licenses/by/4.0/), which permits use, sharing, adaptation, distribution and reproduction in any medium or format, as long as you give appropriate credit to the original author(s) and the source, provide a link to the Creative Commons license and indicate if changes were made.

The images or other third party material in this chapter are included in the chapter's Creative Commons license, unless indicated otherwise in a credit line to the material. If material is not included in the chapter's Creative Commons license and your intended use is not permitted by statutory regulation or exceeds the permitted use, you will need to obtain permission directly from the copyright holder.

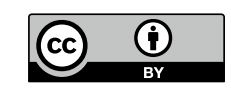

